\title{
Effect of polymyxin B on gram-negative bacterial infection during pregnancy
}

\author{
Gebe fare modelinde gram-negatif bakteriyel enfeksiyona polimiksin B'nin etkisi \\ Mukesh Kumar Jaiswal, Varkha Agrawal, Yogesh Kumar Jaiswal \\ Molecular Biology and Reproductive Immunology Laboratory, School of Studies in Biochemistry, Jiwaji University, Gwalior, India
}

Abstract

Objective: Polymyxin B (PB) is a naturally occurring cationic cyclic decapeptide which is highly bactericidal to Gram-negative bacteria. The objective of this study was to investigate the effect of PB on the viability of developing embryos during pregnancy and to validate its protective effect on the embryotoxic effect of Gram-negative bacterial lipopolysaccharide (LPS).

Material and Methods: Animals were injected intraperitoneally (i.p.) with PB (5-100 $\mu \mathrm{g} / \mathrm{animal})$, (Minimum effective dose) MD of LPS and MD of LPS+PB (5-100 $\mu \mathrm{g} / \mathrm{animal})$ on day 0.5 of pregnancy. The percentage of normal gestational sacs and histopathologic analysis were assessed.

Results: PB treatment of pregnant females disturbs the pregnancy in a dose dependent manner and increases the substantial risk of congenital abnormalities in the growing fetuses of the mother. However, PB does not show any adverse effect on implantation of embryos. The embryotoxic effect of LPS can be prevented completely by $25 \mu \mathrm{g}$ PB/ animal; however other lower and higher doses of PB were not able to protect against the effect of LPS on pregnancy.

Conclusions: Our results demonstrate that $\mathrm{PB}$ has the ability to protect the LPS-induced pregnancy loss but may not be recommended as a safe drug for the treatment of a mother suffering from Gramnegative bacterial infection during pregnancy.

(J Turkish-German Gynecol Assoc 2011; 12: 64-70)

Key words: Gram-negative bacterial infection, lipopolysaccharide, polymyxin B, pregnancy loss, implantation failure

Received: 18 February, 2011

Accepted: 15 March, 2011

\section{Özet}

Amaç: Polimiksin B (PB) Gram-negatif bakterilere karşı son derece bakterisidal olan, doğada bulunan bir katyonik siklik dekapeptiddir. Bu çalışmanın amacı PB'nin gebelik süresince gelişmekte olan embriyonun yaşayabilirliği üzerine etkisini araştırmak ve Gram-negatif bakteriyel lipopolisakkaridin (LPS) embriyotoksik etkisi üzerine koruyucu etkisini doğrulamaktı.

Gereç ve Yöntemler: Hayvanlara gebeliğin 0.5 'inci gününde intraperitoneal olarak (i.p.) PB (5-100 $\mu \mathrm{g} /$ hayvan), minimum etkili doz (MD) LPS ve MD LPS+PB (5-100 $\mu$ g/hayvan) enjekte edildi. Normal gebelik keselerinin yüzdesi ve histopatolojik analiz değerlendirildi.

Bulgular: Gebe dişilerin PB tedavisi doz bağımlı bir şekilde gebeliği kötü yönde etkiler ve annelerin büyümekte olan fetüslerinde konjenital anormalliklerin riskini belirgin olarak artırır. Bununla beraber, embriyoların implantasyonu üzerine PB olumsuz bir etki göstermez. LPS'nin embriyotoksik etkisi $25 \mu \mathrm{g}$ PB/hayvan ile tamamen önlenebilir; bununla beraber daha düşük ve daha yüksek diğer PB dozları gebelik üzerine LPS'nin etkisine karşı koruyucu olamadı.

Sonuçlar: Sonuçlarımız PB'nin LPS'nin tetiklediği gebelik kayıplarını önleyebilme becerisine sahip olduğunu fakat gebelik süresince Gram-negatif bakteriyel enfeksiyon geçiren bir annenin tedavisi için güvenilir bir ilaç olarak önerilemeyeceğini göstermektedir.

(J Turkish-German Gynecol Assoc 2011; 12: 64-70)

Anahtar kelimeler: Gram-negatif bakteriyel enfeksiyon, lipopolisakkarit, polimiksin B, gebelik kaybı, implantasyon başarısızlığı

Geliş Tarihi: 18 Şubat 2011

Kabul Tarihi: 15 Mart 2011

\section{Introduction}

Preterm labor and delivery continues to be the most important unsolved problem in obstetrics. $10-30 \%$ of women with preterm labor have clinically evident and subclinical Gramnegative bacterial infection (1-3). The bacterial endotoxin, lipopolysaccharide (LPS), is the major antigen of the outer membrane of Gram-negative bacteria that possess a toxic effect. Gram-negative bacteria colonize in the genitourinary tract of women and contribute to creating a distinct microbial environment (4). The endotoxins, continually released into the genitourinary tract of the infected pregnant females, may be associated with preterm labor and birth and other perinatal complications.
Several different model systems for inducing preterm labor in mice have been developed over recent years. These involve local (intrauterine or intracervical), extrauterine (e.g., renal), and systemic administration of a variety of substances, such as bacteria, bacterial products from Gram-positive and Gramnegative organisms, inflammatory cytokines, prostaglandins, and others (5). The use of killed bacteria, components of the cell wall (LPS or Lipoteichoic acids) or proinflammatory cytokines (interleukin (IL)-1) create an inflammatory state in the absence of an overt infection. Both of these methods can promote preterm delivery in rodents and non-human primates (6). We developed a Gram-negative bacterial infection model in mouse by the systemic administration of 'minimum dose' (i.e., $250 \mu \mathrm{g} / \mathrm{kg}$ body weight, i.p. on day 0.5 of pregnancy) of

Address for Correspondence: Yogesh Kumar Jaiswal Ph.D., Molecular Biology and Reproductive Immunology Laboratory, School of Studies in Biochemistry, Jiwaji University, Gwalior - 474011 India Phone: +917514016793 e.mail: jaiswalmbri@gmail.com doi:10.5152/jtgga.2011.17 
LPS which is sufficient to cause embryonic cell death (7) and leads to implantation failure on day 5.5 of pregnancy (8). LPS exhibits a variety of toxic and proinflammatory activities that are related to the pathogenesis of Gram-negative bacterial infection (9-11). LPS inhibits the blastocyst implantation in mouse by modulating the level and pattern of expression of different cytokines such as tumor necrosis factor (TNF)- $\alpha$, (12) IL-1 (13) and growth factors such as colony stimulating factor (CSF)-1 (7). LPS-induced DNA damage in preimplantation stage embryos and uterine cells leads to poor pregnancy outcome (14).

Polymyxin $\mathrm{B}(\mathrm{PB})$ is a naturally occurring cationic cyclic peptide isolated from Bacillus polymyxa $(15,16)$. PB is highly bactericidal to Gram-negative bacteria and is considered to be one of the most efficient cell-permeabilizing compounds (17). This capacity is due to its high-affinity binding to the lipid A moiety of LPS in Gram-negative bacteria. PB forms a heptapeptide ring by an amide bond between the C-amino group of diaminobutyric acid (DAB) at position 4 and the carboxyl group of the C-terminal, and a tripeptide tail which is attached to a small fatty acyl chain via a peptide bond. PB is an amphiphilic compound due to the presence of both a polycationic heptapeptide ring containing five positively charged DAB residues and a hydrophobic acyl chain. These positively charged DAB residues of PB interacts with the Lipid A moiety of LPS with an ensuing loss of many of the biological properties of LPS by forming a LPS-PB complex (18). This property of PB may be used in developing it as a novel anti-Gram-negative bacterial drug. However, the therapeutic applications of PB are very limited because of its relatively high toxicity $(19,20)$.

In the field of reproductive medicine, PB has been used as a chemotherapeutic drug in some gynecological pathologies, for treating pregnant females suffering from severe pyelonephritis, endometriosis, tubular obstruction in fallopian tubes and genital tract infections caused by Gram-negative bacteria (21). It has been reported that exposure of mothers to PB in the first trimester of pregnancy does not lead to any congenital abnormalitie (21). However, the use PB during pregnancy is debatable as to whether use of PB as an antagonist of LPS should be promoted or not. Here we investigate the effects of PB on developing embryos and pregnancy outcomes in a Gram-negative bacterial infection mouse model.

\section{Materials and Methods}

\section{Animals}

Park strain mice (6-7 weeks, $\sim 20-21 \mathrm{~g}$ ) used in the study was maintained in our animal care facility at $25 \pm 2{ }^{\circ} \mathrm{C}$ with $12: 12 \mathrm{hr}$ light: dark period. They were regularly fed with pelleted diet (Amrut Laboratory Animal Feed, Pranav Agro Industries, Sangli, $\mathrm{MH}$, India) and drinking water ad libitum. Normal mature adult females were selected for the present study. This study was conducted in accordance with the institutional ethics committee guidelines for the care and use of animals in research.

\section{Design of experiment}

The reproductive cycle was checked and females in proestrus were caged individually overnight with proven fertile male for mating. Vaginal plug was checked next day morning at 9:00 A.M. and the vaginal plug positive females were considered as being on day 0.5 of pregnancy.

\section{Determination of the effect of PB on implantation}

The effect of PB on the implantation of blastocysts was evaluated. Females were divided into two groups of five animals each. The animals of group I received $100 \mu \mathrm{l}$ of sterile normal saline as a control and group II received $100 \mu \mathrm{g}$ PB/animal (InvivoGen, California, USA) in a $100 \mu$ l volume through i.p. route on day 0.5 of pregnancy. Pontamine Blue dye test was performed on day 5.5 of pregnancy to observe the effect of this dose on implantation.

\section{Determination of the effect of PB on post Implantation period of pregnancy}

Pregnant females were divided into five groups of six animals each. Different doses of PB (5, 25, 50 and $100 \mu$ g, i.p.) were given to individual groups on day 0.5 of pregnancy. Control animals received $100 \mu \mathrm{l}$ of normal saline in a similar manner. The effect of PB on the status of pregnancy was assessed on days 9.5 and 14.5 of pregnancy by examining individual uterine horns and gestational sacs for live (pink, round, uniform) and dead (abnormally shaped, hemorrhagic sacs) pups and for resorption (very small, pale and gray sacs with no discernible fetus). Five pregnant females of control and $100 \mu \mathrm{g}$ PB-treated groups were maintained up to the day of parturition to monitor the effect of PB on development of the implants during the post implantation period of pregnancy.

\section{Determination of PB dose effective in preventing the embryotoxic effect of LPS}

Pregnant females were divided into six groups of four animals each. The animals of group I received sterile normal saline, group II received LPS ( $5 \mu \mathrm{g} /$ animal), group III received LPS and PB (5 $\mu \mathrm{g} /$ animal), group IV received LPS and PB (25 $\mu \mathrm{g} /$ animal), group V received LPS and PB (50 $\mu \mathrm{g} /$ animal) and group VI received LPS and PB ( $100 \mu \mathrm{g} /$ animal) i.p. in $100 \mu \mathrm{l}$ volume on day 0.5 of pregnancy. The dose of LPS was the same i.e., $5 \mu \mathrm{g} /$ animal in each LPS and PB treated group. Status of pregnancy was assessed on day 14.5 of pregnancy. Five pregnant females of group I, II and IV were maintained up to the day of parturition to check that normal gestational sacs observed on day 14.5 of pregnancy develop into normal pups or not.

Histopathologic analysis of uterus on day 14.5 of pregnancy in animals treated with LPS and different doses of PB

Histopathologic analysis of uterine horns was carried out according to a standard procedure (22). Uterus of selected groups was collected on day 14.5 of pregnancy and fixed in Bouin's fixative for 22-24 hours. The fixed tissues were processed in a tissue processor (Leica Tissue Processor 1020, Leica Microsystems, Wetzlar, Germany) and embedded in the paraffin wax at $60^{\circ} \mathrm{C}$ with the use of tissue embedder (Leica Tissue Embedder, Wetzlar, Germany). Tissue blocks were sectioned at $4.5 \mu \mathrm{m}$ using a microtome (Leica EG 1106 Microtome, Semi automated, Microm, Wetzlar, Germany). Tissue ribbons were processed in an autostainer (Leica Autostainer XL, 
Wetzlar, Germany) and stained with Hematoxylin and Eosin. Slides were mounted with DPX and observed under a light microscope (Leica DM IL, Wetzlar, Germany) at X5 magnification and photographed.

\section{Statistical analyses}

The results of all the experiment were analyzed by using one way analysis of variance (ANOVA) with Duncan's multiple range test for comparison of the significance level (P) among control and treated values. $\mathrm{p}<0.05$ was considered to be a significant difference among the values compared.

\section{Results}

\section{Effect of PB on implantation}

The effect of PB on implantation was assessed by the presence of positive Pontamine Blue sites in uterine horns on day 5.5 of pregnancy. Uterine horns were recovered from control (Figure 1A) and $100 \mu \mathrm{g}$ PB-treated (Figure 1B) animals on day 5.5 of gestation. No significant difference was observed in the number of implantation sites between control $(9.45 \pm 0.48)$ and PB-treated (9.33 \pm 0.88$)$ animals on day 5.5 of pregnancy (Table 1). However, overcrowded conceptus with abnormal spacing was observed on day 5.5 on pregnancy as compared to controls.

\section{Effect of $\mathrm{PB}$ on post-implantation period of pregnancy}

The effect of PB (100 $\mu \mathrm{g} / \mathrm{animal})$ on the viability of embryos was assessed by examining the gestational sacs for live and dead pups and resorption during the post-implantation period of pregnancy. The uterine horns were recovered from control (Figure 1C) and $100 \mu \mathrm{g}$ PB-treated animals (Figure 1D) on day 9.5 of gestation. No significant difference was observed between the number of gestational sacs present in control $(9.41 \pm 0.41)$ and $100 \mu$ g PB-treated $(8.50 \pm 0.50)$ animals on day 9.5 of gestation (Table 1).

The effect of PB was checked on the viability of embryos on day 14.5 of gestation. Uterine horns were recovered from control (Figure 2A) and $100 \mu \mathrm{g}$ PB-treated animals (Figure 2F) on day 14.5 of gestation. A significantly lower number of normal gestational sacs were observed in $100 \mu \mathrm{g}$ PB-treated animals $(2.50 \pm 1.07)$ compared to the controls $(8.58 \pm 0.23)$ (Table 1$)$. Developmentally normal gestational sacs with no sign of dead pups and resorptions were recovered from the control animals (Figure $2 \mathrm{~K}$ ), whereas only $29.14 \pm 12.46 \%$ of gestational sacs were normal in $100 \mu \mathrm{g}$ PB-treated animals (Figure 2K) on day 14.5 of pregnancy.

The animals treated with normal saline and $100 \mu \mathrm{g}$ PB was kept up to the day of parturition to check the delivery outcome. No pups were recovered from $100 \mu \mathrm{g}$ PB-treated animals, whereas normal pups were observed in control animals $(8.5 \pm 0.19)$ (Table 1). This observation clearly suggests that the gestational sacs, which were normal on day 14.5 of pregnancy in $100 \mu \mathrm{g}$ PB-treated animals, had undergone resorption during the later stages of development.

The effect of lower doses of PB (i.e., 5, 25 and $50 \mu \mathrm{g}$ PB/animal) on pregnancy was evaluated by visual examination of uterine horns and individual gestational sacs on day 14.5 of pregnancy. We found that percentages of normal gestational sacs were only $66.04 \pm 21.63 \%$ in $5 \mu \mathrm{g}$ PB-treated animals (Figure $2 \mathrm{C}, 2 \mathrm{~K}$ ), $40.79 \pm 13.87 \%$ in $25 \mu \mathrm{g}$ PB-treated animals (Figure 2D, 2K) and $43.03 \pm 14.36 \%$ in $50 \mu \mathrm{g}$ PB-treated animal (Fig. 2E, 2K).

Present observations show that $\mathrm{PB}$ treatment in pregnant females disturbs the normal pregnancy in a dose dependent manner and increased the substantial risk of congenital abnor-

Table 1. Effect of PB (100 $\mu \mathrm{g} /$ animal) on embryonic loss during different stages of pregnancy

\begin{tabular}{|l|c|c|c|c|c|}
\hline Treatment & $\begin{array}{c}\text { Number of } \\
\text { animals used }\end{array}$ & $\begin{array}{c}\text { No. of implantation } \\
\text { sites /animal on day } \\
\mathbf{5 . 5} \text { of pregnancy* }\end{array}$ & $\begin{array}{c}\text { No. of gestational } \\
\text { sacs/animal on day } \\
\mathbf{9 . 5} \text { of pregnancy* }\end{array}$ & $\begin{array}{c}\text { No. of gestational } \\
\text { sacs/animal } \\
\text { on day } \mathbf{1 4 . 5}^{*}\end{array}$ & $\begin{array}{c}\text { Number of pups } \\
\text { born/animal * }\end{array}$ \\
\hline Control & 5 & $9.45 \pm 0.48^{\mathrm{a}}$ & $9.41 \pm 0.41^{\mathrm{a}}$ & $8.58 \pm 0.23^{\mathrm{a}}$ & $8.5 \pm 0.19^{\mathrm{a}}$ \\
\hline $\begin{array}{l}100 \mu \mathrm{g} \text { PB treated } \\
\text { animals }\end{array}$ & 5 & $9.33 \pm 0.88^{\mathrm{a}}$ & $8.50 \pm 0.50^{\mathrm{a}}$ & $2.50 \pm 1.07^{\mathrm{b}}$ & $0.00 \pm 0.00^{\mathrm{c}}$ \\
\hline $\begin{array}{l}\text { Data are expressed as mean } \pm 1 \mathrm{SEM} \\
\text { a-cValues bearing non-similar superscripted alphabets differ from each other at } \mathrm{p} \leq 0.05 \text { (based on Duncan's multiple-range test) }\end{array}$
\end{tabular}

Table 2. The effect of protective dose of PB (25 $\mu \mathrm{g} /$ animal) in LPS-induced pregnancy loss

\begin{tabular}{|l|c|c|c|c|}
\hline Treatment & $\begin{array}{c}\text { Number of } \\
\text { animals used }\end{array}$ & $\begin{array}{c}\text { No. of implantation } \\
\text { sites on day 5.5 } \\
\text { of pregnancy* }\end{array}$ & $\begin{array}{c}\text { No. of gestational sacs } \\
\text { on day 14.5 } \\
\text { of pregnancy* }\end{array}$ & $\begin{array}{c}\text { Number of } \\
\text { pups born* }\end{array}$ \\
\hline Control animals & 5 & $8.77 \pm 0.33^{\mathrm{a}}$ & $8.58 \pm 0.23^{\mathrm{a}}$ & $8.5 \pm 0.19^{\mathrm{a}}$ \\
\hline LPS-treated animals & 5 & $0.32 \pm 0.09^{\mathrm{b}}$ & $0.25 \pm 0.13^{\mathrm{b}}$ & $00 \pm 0.00^{\mathrm{c}}$ \\
\hline $\begin{array}{l}25 \mu \mathrm{g} \text { Polymyxin B+ } \\
\text { LPS-treated animals }\end{array}$ & 5 & $8.46 \pm 0.13^{\mathrm{a}}$ & $8.00 \pm 0.00^{\mathrm{a}}$ & $8.33 \pm 0.33^{\mathrm{a}}$ \\
\hline $\begin{array}{l}\text { *Data are expressed as mean } \pm 1 \text { SEM } \\
\text { a-c-Values bearing non-similar superscripted alphabets differ from each other at } \mathrm{p} \leq 0.05 \text { (based on Duncan's multiple-range test) }\end{array}$ \\
\hline
\end{tabular}


malities in the developing fetus. However, none of the tested doses of PB showed any adverse effect on the implantation of blastocyst in mouse.

\section{Effect of PB on LPS}

The effect of PB in LPS-treated females was analyzed on day 14.5 of pregnancy by visual examination of individual gestational sacs recovered from the animals treated with normal saline, LPS and LPS with different doses of PB (i.e., 5, 25, 50 and 100 $\mu \mathrm{g}$ PB/animal).

Gestational sacs were developmentally normal with no sign of dead pups and/or resorption in the control animals on day 14.5 of pregnancy (Figure 2A, 2K). In LPS-treated animals, only $2.19 \pm 1.52 \%$ gestational sacs were normal (Figure $2 \mathrm{~B}, 2 \mathrm{~K}$ ). Percentages of normal gestational sacs were $46.62 \pm 24.26 \%$ in LPS $+5 \mu$ g PB-treated animals (Fig. $2 \mathrm{G}, 2 \mathrm{~K}$ ) and $94.87 \pm 3.1 \%$ in LPS $+25 \mu \mathrm{g}$ PB-treated animals (Figure $2 \mathrm{H}, 2 \mathrm{~K}$ ). The numbers of gestational sacs were the same in uterine horns recovered from LPS $+25 \mu \mathrm{g}$ PB treated $(8.00 \pm 0.00)$ and normal saline $(8.58 \pm 0.23)$ treated animals (Table 2). Percentages of normal gestational sacs were $25.00 \pm 12.21 \%$ in LPS $+50 \mu \mathrm{g}$ PB/animal (Figure 2I, 2K) and 32.23.00 $\pm 12.32 \%$ in LPS $+100 \mu \mathrm{g}$ PB/animal (Figure 2J, 2K).

The present investigation showed that the embryotoxic effect of LPS can be significantly prevented with the dose of $25 \mu \mathrm{g}$ $\mathrm{PB} / \mathrm{animal}(\mathrm{p}<0.05)$. The pregnancy outcome from the normal gestational sacs present on day 14.5 of pregnancy in control and LPS $+25 \mu \mathrm{g}$ PB-treated animals was analyzed. No significant difference was observed in the number of pups recovered

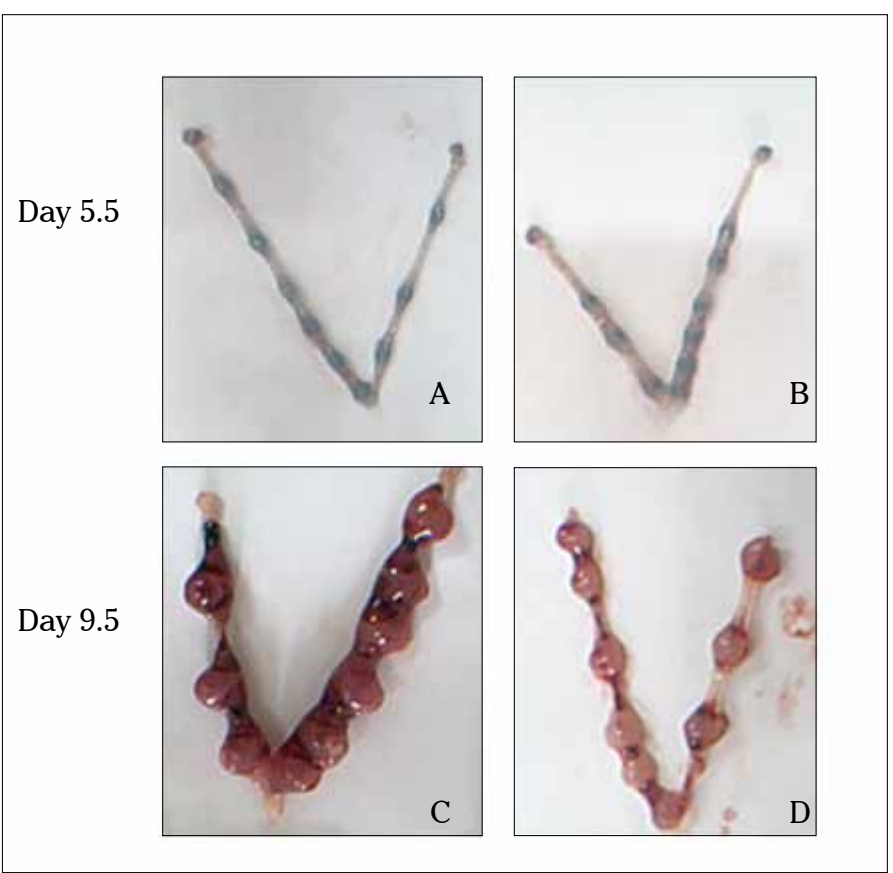

Figure 1. Photographs of the uterine horns showing gestational sacs on day 5.5 and 9.5. Pontamine Blue dye test showing implantation sites in the uterine horns on day 5.5 of pregnancy in (A) control and (B) $100 \mu \mathrm{g}$ PB- treated animals. Uterine horns recovered on day 9.5 of pregnancy in females treated with (C) normal saline and (D) $100 \mu \mathrm{g}$ PB- treated animals from both groups (Table 2). These observations show that the treatment of animals with $25 \mu \mathrm{g}$ PB can protect the embryotoxic effect of LPS (Figure 2K). However, the other tested lower and higher doses of PB with LPS failed to prevent the high percentages of fetal loss. It may also be due to the embryotoxic effect of either LPS and PB or both.

\section{Histopathologic analysis of uterus on day 14.5 of pregnancy in LPS and PB-treated animals}

The histopathologic analysis of the uterus recovered from LPS + PB treated animals was carried out on day 14.5 of pregnancy to evaluate the state of development of fetus and its interaction with uterine epithelium. The cross sections of uterine horns recovered from animals treated with normal saline, LPS, $25 \mu \mathrm{g}$ and $100 \mu \mathrm{g}$ PB, LPS $+25 \mu \mathrm{g}$ PB and LPS $+100 \mu \mathrm{g}$ PB/animal were examined. The normal developing fetus was observed in the cross sections of uterine horns recovered from the control animals on day 14.5 of pregnancy (Figure 3A). The cross-sections of the uterine horns recovered from animals treated with LPS showed uterine lumen closure, hyperplasia of the luminal epithelium, few glands in stromal region, and with no ectoplacental cones (Figure 3B). However, the cross sections of uterine horns recovered from animals treated with $25 \mu \mathrm{g}$ (Figure 3C) and $100 \mu \mathrm{g}$ (Figure 3E) PB showed no fetus, reduced deciduas with none to few degenerated glands in deciduas. Moreover, the deciduas with reduced frond like villous outgrowth were observed in the cross sections of uterine horns recovered from the animals treated with $100 \mu \mathrm{g}$ PB as compared to $25 \mu \mathrm{g}$ PB-treated animals.

The cross sections of the uterine horns recovered from LPS +25 $\mu \mathrm{g}$ PB-treated animals showed normal fetal membrane and developing fetus (Figure 3D) as observed in control pregnancy. However, the cross sections of uterine horns recovered from LPS $+100 \mu \mathrm{g}$ PB-treated animals displayed no fetus and deciduas as compared to control (Figure $3 \mathrm{~F}$ ).

\section{Discussion}

PB has been used widely for treating certain bacterial infections such as the meningial infections caused by Haemophilus influenzae, urinary tract infections of $E$. coli and bacteremia caused by Enterobacter aerogenes etc. and more so for treating the endotoxic or septic shock which is caused by endotoxin (18). Endotoxin is an overwhelmingly powerful poison, the actions of which target virtually every cell-type in the susceptible animal, and in this way endotoxin evokes a multitude of biological responses. Gram-negative bacterial endotoxin can induce both local and systemic activation of immune response, and in extreme cases, this leads to septic shock. Gram-negative bacterial infections of the genito-urinary tract of pregnant women are known to cause fetal abortions or pregnancy loss $(23,24)$. Some of the obstetricians recommended PB treatment in clinics for severe infection caused by Gram-negative bacteria. (21). However, in the present study, it has been observed that PB shows embryotoxic effects during the post-implantation period of normal pregnancy and increases the substantial risk of congenital abnormalities in the developing fetus in a dose 

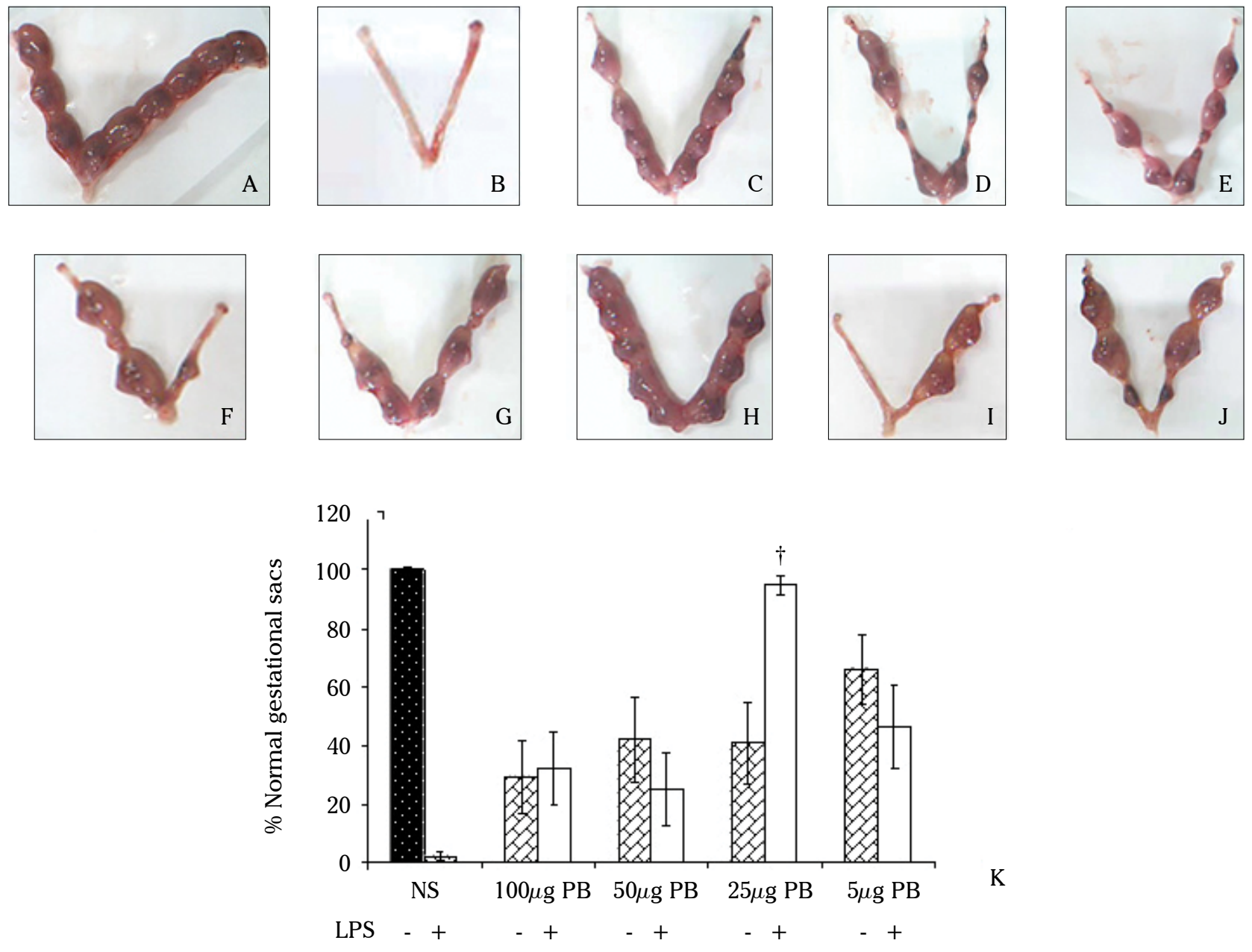

Figure 2. Photographs of the uterine horns showing gestational sacs on day 14.5 of pregnancy in females treated with (A) normal saline, (B) LPS, (C) $5 \mu \mathrm{g}$ PB, (D) $25 \mu \mathrm{g}$ PB (E) $50 \mu \mathrm{g}$ PB, (F) $100 \mu \mathrm{g}$ PB, (G) LPS +5 $\mu \mathrm{g}$ PB, (H) LPS+25 $\mu \mathrm{g}$ PB, (I) LPS+50 $\mu \mathrm{g}$ PB, (J) LPS $+100 \mu \mathrm{g}$ PB; (K) Percentage of normal gestational sacs on day 14.5 of pregnancy in PolymyxinB and LPS-treated animals Note: Data is expressed as mean $\pm 1 \mathrm{SEM}$

$\dagger$ Non-significant to the PBS group ( $\mathrm{p}=0.57$ ), based on Duncan's multiple-range test $\mathrm{NS}=$ Normal saline, $\mathrm{PB}=$ Polymyxin $\mathrm{B}$

dependent manner. We have also shown that PB treatment may protect pregnancy in LPS-treated animals. The molecular mechanism involved in this process is not known. It is not even well established how PB disturbs the pregnancy, because it does not possess any specific and selective toxicity. Our observation of the Pontamine blue test on day 5.5 of pregnancy suggests that PB $(100 \mu \mathrm{g})$ does not affect the blastocyst implantation. However; this dose leads to abortion of the developing fetus in later stages of gestation. Furthermore, treatment of other PB doses shows a very high percentage of fetal rejection in a dose dependent manner.

It has been reported that PB induces hypothermia by modulating the thermoregulatory mechanism in rodents. In addition, it has been demonstrated that an i.v. injection of PB decreases the metabolic rate and heat loss response in rodents, which may be responsible for $\mathrm{PB}$ induced hypothermia that may lead to hemorrhagic condition in rodents (25). It has also been reported that PB induces neuromuscular blockade and its action might be responsible for the decrease in metabolic rate, especially in skeletal muscles. The PB induced myoneural effect is due to its pre-synaptic action that inhibits the release of acetylcholine, which suggests the presence of its receptor at the pre-synaptic sites (25). These observations suggest that PB induced pregnancy loss might be due to a reduction of metabolic rate, heat loss and neuromuscular blockade which may reduce the growth and development of embryos and uterus during pregnancy. We observed that the uterus recovered after PB treatment was abnormal, with loss of flexibility and hemorrhagic gestational sacs as compared to the normal uterus. Our histopathologic observations of uterus on 14.5 day of gestation also support that $\mathrm{PB}$ possesses an abortifacient property in a dose dependent manner. 


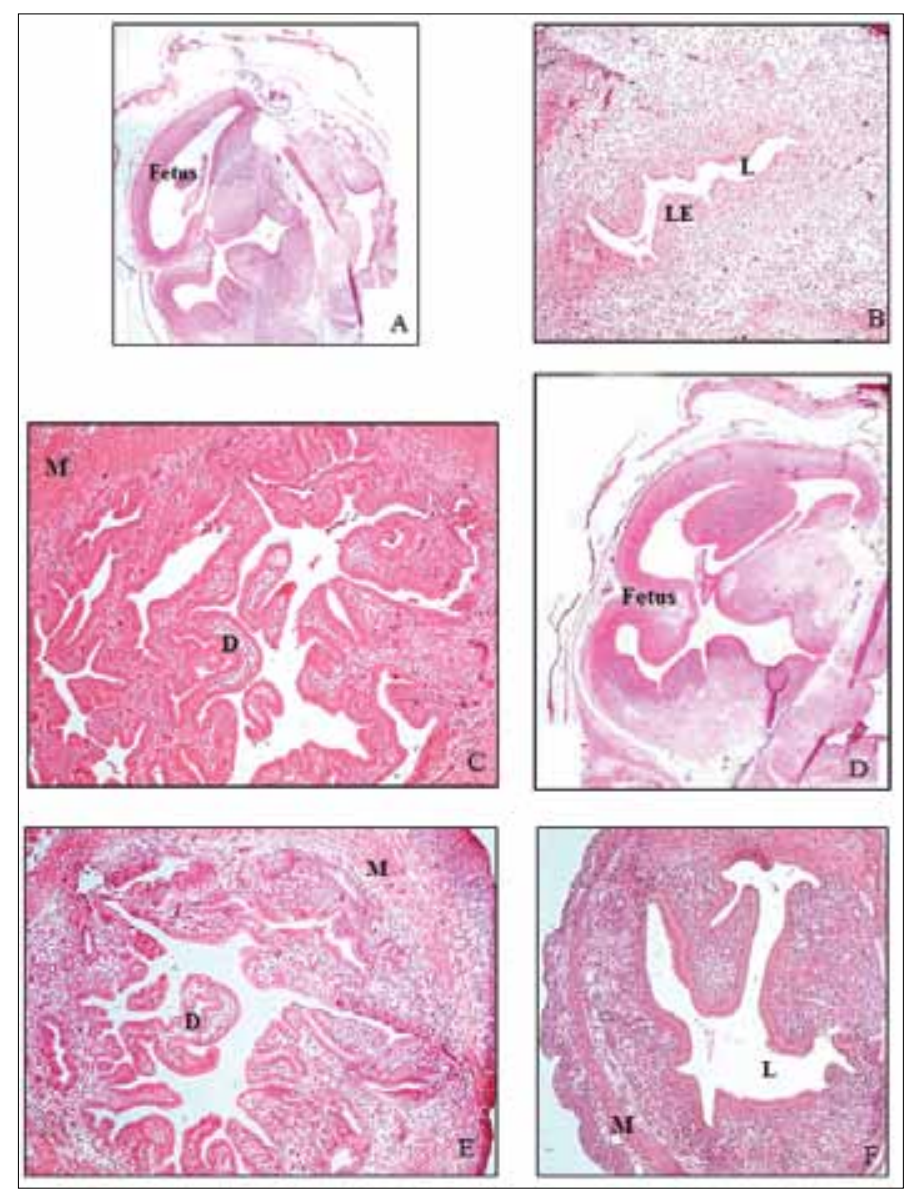

Figure 3. Cross-sections of uterine horn through developing fetus on day 14.5 of pregnancy. Uterine horns recovered from animals treated with (A) normal saline, (B) LPS, (C) $25 \mu \mathrm{g}$ PB, (D) LPS +25 $\mu \mathrm{g}$ PB (E) $100 \mu \mathrm{g}$ PB, (F) LPS $+100 \mu \mathrm{g}$ PB. X50 magnification; $M=$ Myometrium; $L=$ Lumen; $L E=$ Luminal epithelium; $D=$ Decidua (Panel A and D has been edited with the help of Adobe Photoshop software)

In the present study, we observed that $25 \mu \mathrm{g}$ PB is efficient in protecting the effect of LPS-induced early pregnancy loss, whereas its other tested lower and higher doses failed to do so. Our studies show that the embryotoxic effect of LPS can be completely prevented by $25 \mu \mathrm{g} \mathrm{PB} / \mathrm{animal}$. It has been found that $94.87 \pm 3.1 \%$ developmentally normal gestational sacs present in the animals pre-exposed with LPS and treated with $25 \mu \mathrm{g}$ $\mathrm{PB} /$ animal on day 14.5 of gestation, were able to develop into normal and healthy pups, whereas this was not observed with other lower and higher doses of PB. It has been suggested that PB binds to LPS at multiple places and neutralizes its effect. PB is a natural cationic cyclic peptide antibiotic containing a lipophilic and hydrophilic groupment (lipophobic) that binds to the lipid A region of LPS (18). PB binds with high affinity to the lipid A portion and alters the three-dimensional conformation of the LPS molecule. The alteration in the conformation of LPS may possibly inhibit the binding of complex endotoxin-PB to CD14 receptor on monocytes and abrogate the liberation of inflammatory mediators such as the TNF- $\alpha$ (26). Due to this property; PB is used to prevent septic shock $(27,28)$ and it has been used to neutralize LPS-induced TNF- $\alpha$ production (26).
In addition, $\mathrm{PB}$ down regulates the expression of various cytokines such as TNF- $\alpha$, IL-1, IL-10 (29). It has been shown that PB prevents the lethal effect of endotoxin in chick embryos, mice, dogs, goats, foals and horses (30). PB was shown to inhibit LPS-induced intramuscular coagulation, macrophage production of interferon- $\gamma$, TNF- $\alpha$, IL-1, the generalized Shwartzman reaction and LPS-mediated shock (27). These evidences suggest that the protective property of PB against the LPS-induced embryopathy might be due to its ability to inhibit the production of LPS-induced cytokines during the preimplantation period of pregnancy and thus may prevent LPS-induced early pregnancy loss in mouse.

Our present observation suggests that $25 \mu \mathrm{g}$ PB may be an efficient dose for the treatment of Gram-negative bacterial infection without any adverse affect on ongoing pregnancy. However, other doses of PB, with or without LPS, induce a high percentage of fetal resorption. Therefore, PB may not be recommended as a safe drug for the treatment of Gramnegative bacterial infection during pregnancy, because other studied doses are not effective and are even associated with fetal resorption. However, more work is being carried out in our laboratory to determine the mechanism of action of PB during pregnancy. The outcome of the investigation may provide a deeper insight to our current understanding about the roles of the antibiotic as a chemotherapeutic drug for the treatment of women suffering from vaginitis and other urinary tract infections during pregnancy.

\section{Acknowledgments}

We thank the All India Council for Technical Education (AICTE), New Delhi, India; The Rockefeller Foundation, New York, USA for financial support to YKJ; and the Council for Scientific and Industrial Research (CSIR), New Delhi for a JRF and SRF to VA; and the Indian council of Medical research (ICMR), New Delhi for a SRF to MKJ. Financial support from the Department of Science \& Technology, Govt. of India to the School with DSTFIST grant is acknowledged. We thank Dr. MM Chaturvedi Dr. SC Pant and Dr. IK Patro for their generous lab supports.

\section{Conflict of interest}

No conflict of interest was declared by the authors.

\section{References}

1. Romero RM, Sirtori E, Oyarzun C, Avila M, Mazor R, Callahan $\mathrm{V}$, et al. Infection and labor. prevalence, microbiology, and clinical significance of intraamniotic infection in women with preterm labor and intact membranes. Am J Obstet Gynecol 1989; 161: 817-24.

2. Lamont RF. Infection in the prediction and antibiotics in the prevention of spontaneous preterm labour and preterm birth. BJOG 2003; 110: 71-5. [CrossRef]

3. Deb K, Chaturvedi MM, Jaiswal YK. Comprehending the role of LPS in Gramnegative bacterial vaginosis: ogling in to the causes of unfulfilled child wish. Arch Gynecol Obstel 2004; 270: 133-46. [CrossRef]

4. Jaiswal YK, Jaiswal MK, Agrawal V, Chaturvedi MM. Bacterial Endotoxin (LPS) Induced DNA damage in Preimplanting Embryonic and Uterine Cells Inhibit implantation. Fertil Steril 2008; 91: 2095-103. 
5. Hirsch E, Wang H. The molecular pathophysiology of bacterially induced preterm labor: insights from the murine model. J Soc Gynecol Invest 2005; 12: 145-55. [CrossRef]

6. Elovitz MA, Mrinalini C. Animal models of preterm birth. Trends in Endocrinol Metabol 2004; 15: 479-87. [CrossRef]

7. Jaiswal YK, Chaturvedi MM, Deb K. Effect of bacterial endotoxins on uperovulated mouse embryos in vivo: Is CSF-1 involved in endotoxin induced pregnancy loss? Infect Dis Obstet Gynecol 2006; 2006: 32050. [CrossRef]

8. Deb K, Chaturvedi MM, Jaiswal YK. A "minimum dose" of LPS required for implantation failure: assessment of its effect on the maternal reproductive organs and IL-1 $\alpha$ expression in mouse. Reproduction 2004; 128: 87-97. [CrossRef]

9. Annane D, Aegerter P, Jars-Guincestre MC. Guidet B for CUB-Réa Network. Current epidemiology of septic shock. Am J Respirat Crit Care Med 2003; 168: 165-72. [CrossRef]

10. Ginsburg I. The role of bacteriolysis in the pathophysiology of inflammation, infection and post-infection sequelae. Acta Pathologica Microbiologica et Immunologica Scandinavica 2002; 110: 753-70. [CrossRef]

11. Tobin MJ. Critical care medicine in AJRCCM 2002. Am J Respirat Crit Care Med 2003; 167: 294-305. [CrossRef]

12. Deb K, Chaturvedi MM, Jaiswal YK. The role of TNF- $\alpha$ in Gramnegative bacterial LPS induced Implantation failure. Reprod Med Biol 2005; 4: 79-88. [CrossRef]

13. Deb K, Chaturvedi MM, Jaiswal YK. Gram-negative bacterial LPS induced poor uterine receptivity and implantation failure in mouse: alterations in IL-1 $\beta$, expression in the preimplantation embryo and uterine horns. Infect Dis Obstet Gynecol 2005; 13: 125-33. [CrossRef]

14. Jaiswal YK, Jaiswal MK, Agrawal V, Chaturvedi MM. Maternal gramnegative bacterial infection induced apoptosis of the implanting blastocyst. J Turkish-German Gynecol Assoc 2007; 8: 190-4.

15. Ainsworth GC, Brown AM, Brownlee G. 'Aerosporin', an Antibiotic Produced by Bacillus aerosporus Greer. Nature 1947; 160: 263. [CrossRef]

16. Benedict RG, Langlykke AF. Antibiotic Activity of Bacillus polymyxa. J Bacteriol 1947; 54: 24-5.

17. Danner RL, Joiner KA, Rubin M, Patterson WH, Johnson N, Ayers $\mathrm{KM}$, et al. Purification, Toxicity, and Antiendotoxin Activity of PB Nonapeptide. Antimicrob Agents Chemother 1989; 33: 1428-34.
18. Bhor VM, Thomas CJ, Surolia N, Surolia A. Polymyxin B: An ode to an old antidote for endotoxic shock. Mol Bio Syst 2005; 1: 213-22. [CrossRef]

19. Carig WA, Turner JH, Kunin CM. Prevention of the generalized Shwartzman reaction and endotoxin lethality by Polymyxin localized in tissues. Infec Imm 1974; 10: 287-92.

20. Rifkind D. Prevention by Polymyxin of endotoxin lethality in mice. J Bacteriol 1967; 93: 1463-4. [CrossRef]

21. Kazy Z, Puho E, Czeizel AE. Parenteral Polymyxin B treatment during pregnancy. Reprod Toxicol 2005; 20: 181-2. [CrossRef]

22. McManus JFA, Mowry RW. Staining methods histological and histochemical. Paul B. Hoeber Inc, New York 1960; 423.

23. Jaiswal YK, Deb K. Antifertility potentials of Gram-negative bacterial Endotoxins. In: Tripathi G, Kumar A eds. Potentials of Living Resources. New Delhi, India: DPH Publishers 2003; 1-42.

24. Deb K, Chaturvedi MM, Jaiswal YK. Gram-negative bacterial endotoxin induced infertility: A bird's eye view. Gynecol Obstet Invest 2004; 57: 224-32. [CrossRef]

25. Moriyama N, Miyoshi M, Imoto T, Maruyama M, Shido O, Watanabe T. Systemic administration of polymyxin B induces hypothermia in rats via an inhibitory effect on metabolic rate. Europ J of Pharmacol 2006; 541: 38-43. [CrossRef]

26. Haim T, Itzhak O, Sofia C, Mati F. Structure-function studies of Polymyxin B nonapeptide: Implications to Sensitization of GramNegative Bacteria. J Med Chem 2000; 43: 3085-92.

27. Corrigan JJ Jr, Bell BM. Endotoxin-induced intravascular coagulation: prevention with PB sulfate. J Lab Clin Med 1971; 77 : 802-10.

28. Gerard C, Bruyns C, Marchant A, Abramowicz D, Vandenabeele P, Delvaux A, et al. Interleukin 10 reduces the release of tumor necrosis factor and prevents lethality in experimental endotoxemia. J Exp Med 1993; 177: 547-50. [CrossRef]

29. Cardoso LS, Araujo MI, Góes AM, Pacífico LG, Oliveira RR, Oliveira SC. PB as inhibitor of LPS contamination of Schistosoma mansoni recombinant proteins in human cytokine analysis. Microb Cell Fact 2007; 6: 1 .

30. Oliveira LD, Leao MVP, Carvalho CAT Camargo CHR, Valera MC, Jorgea AOC, Unterkircher CS. In vitro effects of calcium hydroxide and PB on endotoxins in root canals. J Dent 2005; 33: 107-14. [CrossRef] 